\title{
THE INFLUENCE OF CLADODE MORPHOLOGY ON THE CANOPY FORMATION OF FORAGE CACTUS PLANTS ${ }^{1}$
}

\author{
MARCELA LÚCIA BARBOSA ${ }^{2}$, THIERES GEORGE FREIRE DA SILVA ${ }^{3 *}$, SERGIO ZOLNIER ${ }^{2}$, SÉRVULO \\ MERCIER SIQUEIRA E SILVA ${ }^{4}$, ANTONIO JOSÉ STEIDLE NETO ${ }^{5}$
}

\begin{abstract}
Here we aimed to evaluate the influence of cladode morphology on the canopy formation of forage cactus plants. The study was carried out in Serra Talhada, the State of Pernambuco, using the IPA Sertânia (IPA), Miúda (MIU), and Orelha de Elefante Mexicana (OEM) clones, which were submitted to three irrigation depths $(2.5,5.0$, or $7.5 \mathrm{~mm})$ and three irrigation intervals $(7,14$, or 28 days) from March 2012 to August 2013. Cladode and plant canopy biometric data were obtained during the experimental period. We found that the characteristics of the second and third order cladodes contributed most to the canopy formation of clones of the genus Nopalea (IPA and MIU), whereas, for the genus Opuntia (OEM), the first and third order cladodes contributed most. Overall, we found that the influence of the cladode variables on the canopy growth of forage cactus is more associated with the characteristics of the genus than to the peculiarities of the clones.
\end{abstract}

Keyword: Statistical analysis. Clones. Biometrics data. Nopalea sp.. Opuntia sp..

\section{ASSOCIAÇÃO MORFOLÓGICA DE CLADÓDIOS COM A FORMAÇÃO DO DOSSEL DA PALMA FORRAGEIRA}

RESUMO - O objetivo foi avaliar a influência das características morfológicas dos cladódios sobre a formação do dossel da palma forrageira. O estudo foi conduzido em Serra Talhada, PE, com os clones IPA Sertânia - IPA, Miúda - MIU e Orelha de Elefante Mexicana - OEM, os quais foram submetidos a três lâminas (2,5; 5,0; e 7,5 mm) e três intervalos de irrigação (7; 14 e 28 dias), no período compreendido entre março 2012 a agosto de 2013. Dados das dimensões dos cladódios e do dossel das plantas foram obtidos ao longo do tempo. A matriz de correlação de Pearson foi elaborada, e análises canônicas e de trilha foram aplicadas para avaliação da associação entre as variáveis. Verificou-se que, as características dos cladódios de $2^{\mathrm{a}}$ e de $3^{\mathrm{a}}$ ordens foram as que mais contribuíram na formação do dossel dos clones do gênero Nopalea (IPA Sertânia e Miúda), enquanto para a Orelha de Elefante Mexicana do gênero Opuntia foram as dos cladódios de primeira $1^{\mathrm{a}}$ e $3^{\mathrm{a}}$ ordens. Conclui-se que, a influência das variáveis dos cladódios sobre o crescimento do dossel da palma forrageira esteve mais associada às características do gênero, do que a peculiaridades dos clones.

Palavras-chave: Análise estatística. Clones. Dados biométricos. Nopalea sp.. Opuntia sp..

\footnotetext{
${ }^{*}$ Corresponding author

${ }^{1}$ Received for publication in $06 / 08 / 2016$; accepted in 03/15/2017.

Paper extracted from the master's dissertation of the first author.

${ }^{2}$ Department of Agricultural Engineering, Universidade Federal de Viçosa, Viçosa, MG, Brazil; marcelalucia.ufrpe@gmail.com, zolnier@ufv.br.

${ }^{3}$ Academic Unit of Serra Talhada, Universidade Federal Rural de Pernambuco, Serra Talhada, PE, Brazil; thieres freire@yahoo.com.br.

${ }^{4}$ Experimental Unit of Arcoverde, Instituto Agronômico de Pernambuco, Arcoverde, PE, Brazil; servulo.mercier@yahoo.com.br.

${ }^{5}$ Universidade Federal de São João Del-Rei, Sete Lagoas, MG, Brazil; steidle@gmail.com.
} 


\section{INTRODUCTION}

As a photosynthetic structure, leaves play a primordial role in plant growth, being in harmony with the other organs and with the edaphoclimatic conditions. Leaves are mostly responsible for the interception of solar radiation, which will promote the metabolic processes of sugar formation and the accumulation of plant mass (GIBSON et al., 2011). The amount of radiation absorbed, as well as water and nutrient supplies, are productive indicators (WEERAKKODY; SURIYAGODA, 2015).

In addition to presenting various physiological adaptations, such as the nocturnal uptake of $\mathrm{CO}_{2}$ for greater efficiency of water use, Cacti species, such as the cactus forage, display morphological adaptations in their photosynthetic structures. Their leaves are atrophied, with the appearance of thorns in their place, so that photosynthesis is carried out in structures called cladodes (PEÑA-VALDIVIA et al., 2008; SILVA et al., 2010; SILVA et al., 2014a).

Clones of cactus forage of the Opuntia and Nopalea genera are widely grown in the northeast of Brazilian, especially Orelha de Elefante Mexicana, which belongs to the Opuntia genus, and Miúda and IPA Sertânia of genus Nopalea. These clones are widely used because of their resistance to Carmim cochineal, their major pest, as well as their use as an animal feed source, especially during the dry season (QUEIROZ et al., 2015; SILVA et al., 2015).

The distribution, size, shape, and number of cladodes of the different clones define the canopy architecture of the forage cactus plants (FLORES-HERNÁNDEZ et al., 2004; SILVA et al., 2010; PINHEIRO et al., 2014; SILVA et al., 2015), which will affect the photosynthetic capacity of the crop and, therefore, its yield. However, other factors such as irrigation management, fertilization, spacing, among others, climatic conditions, and growth habit can also influence the architecture of these plants (SILVA et al., 2014a; SILVA; SANTOS, 2006). Thus, the association between the growth of cladodes and the plants allows us to identify which characteristics will contribute most to the formation of the canopy of the forage cactus.

Canonical correlation analysis determines the linear relationship between groups or sets of variables, identifying the existence and the maximum correlation between different groups (BRUM et al., 2011). Track analysis complements this information, revealing whether the relationship between the variables is a cause or an effect or influenced by others, identifying which variables have the greatest weight and contribution. These approaches have been used when testing the interrelationships between characteristics of cladodes, plant, and forage cactus yields conducted under dryland conditions (PEÑA-VALDIVIA et al., 2008; SILVA et al., 2010; NEDER et al., 2013;
PINHEIRO et al., 2014; SILVA et al., 2015).

The objective of this study was to evaluate the influence of the morphological characteristics of the cladodes on the canopy formation of the forage cactus.

\section{MATERIAL AND METHODS}

Clones of forage cactus were planted at the Instituto Agronômico de Pernambuco ( $7^{\circ} 56^{\prime} 20^{\prime \prime} \mathrm{S}$; $38^{\circ} 17^{\prime} 31^{\prime \prime} \mathrm{O} ; 498 \mathrm{~m}$ ), in Serra Talhada, the state of Pernambuco in the Brazilian semi-arid region, in February 2010. The soil was classified as a yellow-red eutrophic Argisol with sandy loam texture. The spacing adopted in the experiment was $1.6 \times 0.2 \mathrm{~m}$, with rows in a counter line. During the first cycle, cultivation was conducted in dry conditions until March 2012, when the harvest was carried out, maintaining only the basal cladode. From this date, the experimental period of the present study was started, characterizing the second production cycle, which finished in August 2013, totaling 532 days.

The forage cactus was arranged in a random block design, in a factorial arrangement of $3 \times 3 \times 3+3$ with split-split-plot, plus one control of each clone, and three replications, totalizing 90 experimental split-plots. The plots were composed of three fixed water depths for water restoration in the soil (L1: $2.5 \mathrm{~mm}, \mathrm{~L} 2: 5.0 \mathrm{~mm}$ and L3: $7.5 \mathrm{~mm}$, plots), the subplots for three frequencies (F1: 7 days; F2: 14 days, and F3: 28 days, subplots), and the split-split plots by the IPA-Sertânia - IPA (Napolea cochenillifera (L.) Salm-Dick.), Miúda - MIU (Napolea cochenillifera (L.) Salm-Dick.) and Orelha de Elefante Mexicana - OEM (Opuntia stricta (Haw.) Haw.).

In total, the experiment presented 90 split-split-plots, each composed of 4 rows of 20 plants, totaling 80 plants, with an area of $25.6 \mathrm{~m}^{2}$ and useful area of $11.52 \mathrm{~m}^{2}$. The useful area consisted of 32 plants located in the two central rows.

Clones of forage cactus received 756 (L7.5 F7), 672 (L5.0 F7), 622 (L7.5 F14), 586 (L2.5 F7), 579 (L5.0 F14), 555 (L7.5 F28), 536 (L2.5 F14), 535 (L5.0 F28), 514 (L2.5 F28) and 493 (Control) $\mathrm{mm}^{\text {year }}{ }^{-1}$ of water.

Irrigation was carried out using a drip system (drippers spaced at $0.40 \mathrm{~m}$ ). Crop treatments were carried out to eliminate weeds, such as herbicide application, as well as disease control, whenever necessary. Monthly fertilization was done with the application of $50 \mathrm{~kg} \mathrm{ha}{ }^{-1}$ of NPK formulation 14-00-18, according to the recommendation of the Agronomic Institute of Pernambuco.

The structural characteristics of forage cactus clones were followed-up in 13 monitoring campaigns, according to days after cutting - DAC 
$(07 / 24 / 2012$ - DAC 146, 08/22/2012 - DAC 175 , 09/19/2012 - DAC 203, 10/27/2012 - DAC 241, $11 / 24 / 2012$ - DAC 269, 12/22/2012 - DAC 297, $01 / 26 / 2013$ - DAC 332, 02/23/2013 - DAC 360, 03/23/2013 - DAC 388, 04/27/2013 - DAC 423, 05/25/2013 - DAC 451, 07/06/2013 - DAC 493, 07/27/2013 - DAC 514).

In these campaigns, data on plant growth and cladodes were obtained, and measurements were always performed in the same plants. In the cladode, measurements were made up to the $4^{\text {th }}$ order of appearance, from a representative branch of the plant. These measurements included the length of cladodes (BCL, CL1, CL2, CL3 and CL4, where $\mathrm{B}$ - base cladode and 1, 2, 3 and 4, orders of cladode emergence), width (BCW, CW1, CW2, CW3 and $\mathrm{CW} 4)$, the perimeter (BCP, CP1, CP2, CP3 and CP4) and thickness (BCT, CT1, CT2, CT3 and CT4), which were measured with a tape measure and a plastic caliper. In addition, the area values of cladodes were calculated for all orders (BCA, CA1, CA2, CA3 and CA4), using statistical models adjusted by Silva et al. (2014a) for clones, according to data on length and width of cladodes.

The plant measurements consisted of structural characteristics obtained during the biometric monitoring campaigns. In this group, the height of the plant (HP, from the soil surface to the highest cladode) and the width of the plant (PW, at the widest ends) were recorded. These data were obtained using a tape measure, and the number of total cladodes in each plant (TNC) was counted. Finally, a classification was made according to the order of appearance of the cladodes, ranging from the first order ( $\mathrm{NC1}$, the first units to appear from the basal cladode) to the fourth order (NC2, NC3, NC4), based on the clone. The cladode area index (CAI) was determined by the ratio between the sum of the cladode areas and the plant spacing $(1.6 \times 0.2 \mathrm{~m})$.

The experimental data were subdivided into two groups: A) structural characteristics of the plant: "Plant"; and, B) structural characteristics of the cladodes: "Cladodes". The elements of the first group were considered as explanatory variables and the second as response variables.

The Plant group was represented by plant height and width (PH, PW); total number of cladodes (TNC); number of cladodes in order, ranging from 1 to 4 on the clone basis ( $\mathrm{NCOx}$ ) and the cladode area index $(\mathrm{CAI})$, which was determined by the ratio between the sum of the area of cladodes and the planting spacing $(1.6 \times 0.2 \mathrm{~m})$. The area of the cladodes (CA) was obtained using models proposed by Silva et al. (2014b), which were adjusted for the clones IPA Sertânia, Miúda and Orelha de Elefante Mexicana, based on data of length and width of the cladodes.

The Cladode group consisted of the following variables: cladode length (CL1, CL2, CL3 and CL4), cladode width (CW1, CW2, CW3 and CW4), cladode thickness (CT1, CT2, CT3 and CT4), cladodes perimeter (CP1, CP2, CP3 and CP4), and cladodes area from first to fourth order (CA1, CA2, CA3 and CA4).

To perform the analyses, the cladodes up to the third order of appearance were included for IPA and OEM clones and up to the $4^{\text {th }}$ order for the MIU clone. This procedure was necessary because the number of fourth-order cladodes for IPA and OEM and fifth order clones for MIU was reduced. Thus, to avoid misinterpretation of results, it was decided not to count these cladodes in small numbers.

Also, the grouped data for each clone were mean values of the plant growth and cladode variables, regardless of the water regimes (water depth $\times$ frequency), that is, the average of each variable was derived from 30 observations, referring to the experimental split-plots with the same clone.

"Plant" (Response) and "Cladodes" (Explanatory) groups were interrelated to evaluate the individual contribution of the morphological characteristics of the cladodes on the formation of the vegetative canopy of the plants.

The experimental data were first submitted to the Lilliefors test to verify their normality at a significance level of $5 \%$.

Then, the response variables were related to the explanatory variables by means of the Pearson Correlation Matrix. In this analysis, the existence, direction, and intensity of the linear relationship between the groups of variables were evaluated by means of Pearson's linear correlation coefficient (r), between $-1 \mathrm{a}+1$. Values closer to 1 indicate the existence of a strong linear relationship, whereas closer to zero is the existence of a weak linear correlation between the variables. The relationship between explanatory variables and responses was obtained by the equation:

$$
\mathrm{r}_{\mathrm{XY})}=\frac{\operatorname{Cov}(\mathrm{X}, \mathrm{Y})}{\sqrt{\mathrm{V}(\mathrm{X}) \cdot \mathrm{V}(\mathrm{Y})}}=\frac{\sigma(X, Y)}{\sigma(X) \cdot \sigma(Y)}
$$

where: $r_{(X Y)}$ is the Pearson correlation coefficient for the variables $\mathrm{X}$ (response) and $\mathrm{Y}$ (explanatory); $\sigma(X, Y)$, the covariance between the variables $X$ and $\mathrm{Y}$; and $\sigma(\mathrm{X})$ and $\sigma(\mathrm{Y})$ are the standard deviation of the variables $\mathrm{X}$ and $\mathrm{Y}$, respectively.

The classification of the intermediate Pearson correlation coefficients was interpreted according to the one used by Thomaz et al. (2012), which comprised the following ranges: 0 to 0.19 , "very weak"; 0.20 to 0.39 , "weak"; 0.40 to 0.69 , "moderate"; 0.70 to 0.89 , "strong" and 0.90 to 1.00 , "very strong". In addition, the correlation signal was analyzed as positive $(+1)$ or negative $(-1)$ and the significance of the coefficients $(p<0.01$ and $p<0.05)$ was analyzed by Student's t-test.

For the multicollinearity analysis, only the data of the explanatory variables correlated with at least one of the response variables were used. In this analysis, a new data screening was performed, 
discarding the variables that, within the same group, presented correlation with each other with strong multicollinearity (NC >100) (TOEBE; CARGNELUTTI FILHO, 2013). The presence of strong multicollinearity may lead to misinterpretations of the analyses, which may lead to inconsistent estimates of canonical correlation coefficients, as well as an overestimation of the effects of the explanatory variables on the response variables.

In the canonical correlations, only the variables with weak multicollinearity $(\mathrm{NC}<100)$ were used (TOEBE; CARGNELUTTI FILHO, 2013), in which the associations between groups of variables were evaluated, such that the linear correlation between these combinations was maximal. In this analysis, the canonical variables must be orthogonal, that is, linearly independent of each other. The canonical axes were set based on the number of variables of the smallest group, so that the canonical correlations between them were evaluated by means of the Chi-square test, at the level of $1 \%$ of probability. The following equation was applied for the determination of the canonical coefficients between the groups of variables (FERREIRA, 2011):

$$
\rho_{(\mathrm{U}, \mathrm{V})}=\operatorname{Cov}(\mathrm{U}, \mathrm{V})=\frac{\mathrm{X}^{\mathrm{T}} \sum_{12} \mathrm{Y}}{\sqrt{\mathrm{X}^{\mathrm{T}} \sum_{11} \mathrm{X}} \sqrt{\mathrm{Y}^{\mathrm{T}} \sum_{22} \mathrm{Y}}}
$$

where: $\mathrm{X}^{\mathrm{T}} \sum_{12} \mathrm{Y}$ is the covariance among the canonical variables $\mathrm{U}$ and $\mathrm{V} ; \sqrt{\mathrm{X}^{\mathrm{T}} \sum_{11} \mathrm{X}}$ is the standard deviation of the canonical variable $U$ and $\sqrt{\mathrm{Y}^{\mathrm{T}} \sum_{22} \mathrm{Y}}$ is the standard deviation of the canonical variable $\mathrm{V}$.

In the track analysis, the correlation coefficient was unfolded, allowing us to determine the degree of the effect of an explanatory variable on the response variable, by means of the track coefficient. In this analysis, the coefficient of partial correlation between two variables was calculated, disregarding the effect of the others, by means of the following relationship:

$$
r_{(X i Y, Z)}=\frac{r_{X i}-r_{X i Z} \cdot r_{Y Z}}{\sqrt{\left(1-r^{2} \mathrm{XiZ}\right) \cdot\left(1-r^{2} Y Z\right)}}
$$

where $\mathrm{i}$ is a response variable, $\mathrm{r}_{\mathrm{XiZ}}$ is the correlation coefficient between a response variable and $n^{\text {th }}$ explanatory variables; $\mathrm{r}_{\mathrm{YiZ}}$ is the correlation coefficient between the response variable and the $n^{\text {th }}$ explanatory variables. The significance of the partial correlation is identical to that used in the Pearson correlation.

All analyses were carried out in the statistical software "GENES" (CRUZ, 2006).

\section{RESULTS AND DISCUSSION}

For clones IPA Sertânia (IPA), Miúda (MIU) and Orelha de Elefante Mexicana (OEM), we found that, in the Pearson's correlation between growth characteristics of cladodes and plants, nearly all the characteristics of the cladodes contributed to the formation and architecture of the vegetative canopy (Table 1).

For the IPA clone, the characteristics that represented the plant were the width (PW) and the numbers of cladodes of $1^{\text {st }}(\mathrm{NC} 1)$ and $3^{\text {rd }}(\mathrm{NC} 3)$ orders, which correlated with base cladodes (CB) and $1^{\text {st }}, 2^{\text {nd }}$, and $3^{\text {rd }}$ cladodes $(\mathrm{CC} 1, \mathrm{CC} 2, \mathrm{CC} 3, \mathrm{EC} 1$, $\mathrm{PC} 1, \mathrm{ACB}$ ), and provided coefficients classified as moderate to very strong (Table 1 ).

In the MIU, the representative characteristics of plant growth were $\mathrm{PW}, \mathrm{NC} 1, \mathrm{NC} 3, \mathrm{NC} 4$ and cladode area index (CAI), which had a moderate to very strong correlation with the base cladodes and those of the $2^{\text {nd }}, 3^{\text {rd }}$ and $4^{\text {th }}$ orders $(E C B, E C 3, P C 2$, $\mathrm{PC} 3, \mathrm{AC} 4)$

For OEM, the representative plant characteristics were height $(\mathrm{PH}), \mathrm{NC} 1, \mathrm{NC} 3$, and CAI, which correlated with characteristics of base cladodes and those of the $1^{\text {st }}$ and $3^{\text {rd }}$ order $(\mathrm{CC} 1$, $\mathrm{ECB}, \mathrm{EC} 1, \mathrm{EC} 3, \mathrm{PC} 1, \mathrm{ACB})$, providing coefficients that were classified as moderate to very strong.

The canonical correlation analysis allowed us to identify the dependence between the group of structural characteristics of the cladodes and the group of the structural characteristics of the plants. For the IPA clone (Table 2), the first canonical axis $\left(0.997^{* *}\right)$ showed that the plants with the largest widths (PW) and the highest number of $1^{\text {st }}(\mathrm{NC} 1)$ and $3^{\text {rd }}(\mathrm{NC} 3)$ order cladodes were those with higher $1^{\text {st }}, 2^{\text {nd }}$ and $3^{\text {rd }}$ order cladodes, in addition to the largest basal cladodes.

Canonical correlations were significant for the first and second pair of canonical variables of the MIU clone (Table 3). It was observed in the first canonical axis $(0.998 * *)$ that plants with higher amounts of $1^{\text {st }}, 3^{\text {rd }}$ and $4^{\text {th }}$ order cladodes and higher CAI were those with higher $2^{\text {nd }}, 3^{\text {rd }}$ and $4^{\text {th }}$ cladode orders, as well as the greater thickness of the base and the third order cladodes. In the second canonical axis $(0.984 *)$, plants with a lower number of $4^{\text {th }}$ order cladodes and with lower CAI were those that presented lower thicknesses of the basal and $3^{\text {rd }}$ order cladodes, as well as a smaller area of the $4^{\text {th }}$ order cladodes. 
Table 1. Pearson correlation matrices among the variables of the response group "Plant" (structural characteristics of the plants) with the "Cladode" explanatory group (structural characteristics of the cladodes) of forage cactus clones (IPA Sertânia - IPU, Miúda - MIU and Orelha de Elefante Mexicano - OEM), under irrigated conditions, in a semi-arid environment.

\begin{tabular}{lccccccl}
\hline \multirow{5}{*}{ IPA } & & CL1 & CL2 & CL3 & CT1 & CP1 & BCA \\
& PW & $0.613^{*}$ & $0.96^{* *}$ & $0.894^{* *}$ & $0.867^{* *}$ & $0.837^{* *}$ & $0.613^{*}$ \\
& NC1 & 0.454 & $0.898^{* *}$ & $0.611^{*}$ & 0.524 & $0.811^{* *}$ & 0.304 \\
& NC3 & $0.653^{*}$ & $0.803^{* *}$ & $0.939^{* *}$ & $0.864^{* *}$ & $0.706^{* *}$ & $0.647^{*}$ \\
\hline \multirow{5}{*}{ MIU } & & BCA & CT3 & CP2 & CP3 & CA4 & \\
& PW & 0.507 & $0.765^{* *}$ & $0.617^{*}$ & $0.703^{* *}$ & $0.592^{*}$ & \\
& NC1 & 0.201 & $0.566^{*}$ & $0.879^{* *}$ & $0.656^{*}$ & 0.273 & \\
& NC3 & $0.679^{*}$ & $0.942^{* *}$ & $0.817^{* *}$ & $0.975^{* *}$ & $0.752^{* *}$ & \\
& NC4 & $0.775^{* *}$ & $0.924^{* *}$ & $0.654^{*}$ & $0.884^{* *}$ & $0.813^{* *}$ & \\
& CAI & $0.774^{* *}$ & $0.964^{* *}$ & $0.829^{* *}$ & $0.913^{* *}$ & $0.878^{* *}$ & \\
\hline \multirow{5}{*}{ OEM } & & CLBCA1 & BCT & CT1 & CT3 & CP1 & BCA \\
& PH & $0.889^{* *}$ & $0.639^{*}$ & $0.744^{* *}$ & $0.7 * *$ & $0.724^{* *}$ & 0.519 \\
& NC1 & -0.529 & -0.245 & -0.285 & $-0.868^{* *}$ & -0.437 & -0.066 \\
& NC3 & $0.635^{*}$ & $0.617^{*}$ & $0.775^{* *}$ & 0.289 & 0.515 & 0.244 \\
& IAC & $0.953^{* *}$ & $0.844^{* *}$ & $0.913^{* *}$ & $0.608^{*}$ & $0.847^{* *}$ & $0.595^{*}$ \\
\hline
\end{tabular}

Plant Group: PH - plant height, PW - plant width, CAI - cladode area index, NC1 first order cladode number, NC2 - second order cladode number, NC3 - third order cladode number, NC4 - fourth order cladode number.

Cladode number: BCL - basal cladode length, first order cladode length, CL1 - first order cladode length, CL2 - second order cladode length, CL3 - third order cladode length, CW1 - first order cladode width, BCW - basal cladode width, CT1 - first order cladode thickness, CT2 - second order cladode thickness, CT3 - third order cladode thickness, BCP - base cladode perimeter, CP1 - first order cladode perimeter, CP2 - second order cladode perimeter, CP3 - third order cladode perimeter, BCA - basal cladode area, CA4 - fourth order cladode area.

**, *Significant at 1 and $5 \%$, respectively, by t-test.

Table 2. Canonical correlations and canonical pairs between the "Plant" group (structural characteristics of the plants) and the "Cladode" group (structural characteristics of cladodes) of the IPA Sertânia - IPA clone under irrigated conditions in a semi-arid environment.

\begin{tabular}{ccccr}
\hline \multirow{2}{*}{ Groups } & \multirow{2}{*}{ Variables } & \multicolumn{3}{c}{ Canonical factors } \\
\cline { 3 - 5 } & & $1^{\circ}$ & $2^{\circ}$ & $3^{\circ}$ \\
\hline \multirow{3}{*}{ I - Plant } & PW & 0.998 & -0.041 & 0.039 \\
& NC1 & 0.836 & 0.428 & -0.343 \\
& NC3 & 0.901 & -0.346 & -0.262 \\
& & & & \\
& CL1 & 0.612 & -0.237 & -0.280 \\
II - Cladode & CL2 & 0.973 & 0.223 & 0.004 \\
& CL3 & 0.887 & -0.390 & -0.190 \\
& CT1 & 0.853 & -0.391 & 0.251 \\
& CP1 & 0.851 & 0.220 & -0.114 \\
Canonical correlation & BCA & 0.597 & -0.420 & 0.216 \\
$\chi^{2}$ & & $0.997^{* *}$ & 0.918 & 0.386 \\
Degrees of freedom & & 49 & 14 & 1 \\
\hline
\end{tabular}

Where: Plant group: PW - plant width, NC1 - first order cladode number, NC3 - third order cladode number; Cladode Group: CL1 - first order cladode length, CL2 - second order cladode length, CL3 - third order cladode length, CT1 - first order cladode thickness, CP1 - first order cladode perimeter and $\mathrm{BCA}$ - base cladode area. ${ }^{*}$ Significant at $1 \%$ by the Chi-square test.

For the OEM clone (Table 4), only the first canonical axis was significant $(0.999 * *)$. In this axis, plants with higher CAI, higher heights $(\mathrm{PH})$, and lower $\mathrm{NC1}$ were those with the greatest length, perimeter, and thickness of base cladodes, as well as those of $1^{\text {st }}$ and $3^{\text {rd }}$ orders.
It was observed that the length of the third-order cladodes was the characteristic that most contributed to the increase in the number of cladodes of the same order, either by direct or indirect effect (via $\mathrm{CC} 1, \mathrm{CC} 2$, $\mathrm{EC} 1, \mathrm{PC} 1, \mathrm{ACB})$. 
Table 3. Canonical correlations and canonical pairs between the "Plant" group (structural characteristics of plants) and the "Cladode" group (structural characteristics of cladodes), of Miúda - MIU clone, under irrigated conditions, in a semi-arid environment.

\begin{tabular}{cccrrrr}
\hline \multirow{2}{*}{ Groups } & \multirow{2}{*}{ Variables } & \multicolumn{4}{c}{ Canonical factors } \\
\cline { 2 - 6 } & & \multicolumn{1}{c}{$1^{\text {st }}$} & $2^{\text {nd }}$ & $3^{\text {rd }}$ & $4^{\text {th }}$ & $5^{\text {th }}$ \\
\hline \multirow{3}{*}{ I - Plant } & PW & 0.672 & -0.326 & 0.034 & 0.642 & -0.169 \\
& NC1 & 0.836 & 0.217 & -0.365 & 0.115 & 0.328 \\
& NC3 & 0.921 & -0.338 & 0.158 & 0.103 & 0.041 \\
& NC4 & 0.756 & -0.538 & 0.197 & 0.214 & 0.231 \\
& CAI & 0.824 & -0.535 & -0.170 & 0.016 & 0.073 \\
& & & & & & \\
II - Cladode & BCT & 0.444 & -0.787 & 0.079 & -0.126 & 0.401 \\
& CT3 & 0.817 & -0.557 & 0.006 & 0.151 & -0.016 \\
& CP2 & 0.933 & -0.023 & -0.358 & -0.026 & -0.023 \\
& CP3 & 0.929 & -0.323 & 0.139 & -0.111 & -0.034 \\
Canonical correlation & AC4 & 0.537 & -0.820 & -0.052 & -0.135 & -0.134 \\
$\chi^{2}$ & & $0.998 * *$ & $0.984 *$ & 0.835 & 0.394 & 0.212 \\
Degrees of freedom & & 66 & 32 & 9 & 1 & 0 \\
\hline
\end{tabular}

Where: Plant group: PW - plant width, NC1 - first order cladode number, NC3 - third order cladode number, NC4 - fourth order cladode number, IAC - cladode area index; Cladode Group: ECB - basal cladode thickness, CT3 - third order cladode thickness, PC2 - second order cladode perimeter, PC3 - third order cladode perimeter, AC4 - fourth order cladode area. **, *Significant at 1 and $5 \%$, respectively, by the Chi-square test.

Table 4. Canonical correlations and canonical pairs between the "Plant" group (structural characteristics of the plants) and the "Cladode" group (structural characteristics of the cladodes), of Orelha de Elefante Mexicana - OEM clone, under irrigated conditions, in a semi - arid environment.

\begin{tabular}{ccrrrr}
\hline \multirow{2}{*}{ Groups } & \multirow{2}{*}{ Variables } & \multicolumn{4}{c}{ Canonical factors } \\
\cline { 3 - 6 } & & \multicolumn{1}{c}{$1^{\text {st }}$} & $2^{\text {nd }}$ & $3^{\text {rd }}$ & $4^{\text {th }}$ \\
\hline \multirow{3}{*}{ I - Plant } & PH & 0.885 & 0.186 & 0.329 & -0.273 \\
& CN1 & -0.730 & 0.621 & -0.123 & -0.257 \\
& CN3 & 0.465 & 0.696 & 0.038 & 0.546 \\
& CAI & 0.869 & 0.475 & -0.021 & -0.137 \\
& & & & & \\
II - Cladode & CT1 & 0.952 & 0.286 & 0.001 & 0.020 \\
& BCT & 0.737 & 0.439 & -0.411 & -0.014 \\
& CT1 & 0.792 & 0.533 & -0.088 & 0.236 \\
& CT3 & 0.883 & -0.309 & 0.059 & 0.320 \\
Canonical correlation & CP1 & 0.841 & 0.236 & -0.327 & -0.091 \\
$\chi^{2}$ & BCA & 0.472 & 0.309 & -0.180 & -0.698 \\
\hline Degree of freedom & & $0.999 * *$ & 0.944 & 0.674 & 0.458 \\
\hline
\end{tabular}

Where: Plant Group: PH - plant height, NC1 - number of first order cladodes, NC3 - number of third order cladodes, CAI - cladode area index; Cladode Group: CL1 - first order cladode length, EC1 - first order cladode thickness, EC3 - third order cladode thickness, PC1 - first order cladode perimeter, BCA - base area cladode. ${ }^{*}$ Significant at $1 \%$ by the Chi-square test.

In the unfolding of the correlation coefficients between characteristics of cladodes and plant for IPA clone (Table 5), it was verified that the largest plants (PW) and with the highest number of cladodes of the first order (CN1) were those that had higher second order cladodes. These characteristics excelled the others, with direct and indirect effects (via CL1,
CL3, CT1, CP1, BCA). It was observed that the length of the third order cladodes was the characteristic that most contributed to the increase in the number of cladodes of the same order, either by direct or indirect effect (via CL1, CL2, CT1, CP1, BCA). 
Table 5. Pearson's correlation coefficient on direct and indirect effects among the variables of the response group "Plant" (structural characteristics of plants), with the variables of the explanatory group "Cladode" (structural characteristics of cladodes), IPA Sertânia clone - IPA, under irrigated conditions, in a semi-arid environment.

\begin{tabular}{|c|c|c|c|c|}
\hline Variable & Effect & PW & CN1 & $\mathrm{CN} 3$ \\
\hline \multirow{7}{*}{ CL1 } & CL1 direct effect & 0.037 & - & 0.127 \\
\hline & via CL2 indirect effect & 0.399 & - & 0.056 \\
\hline & via CL3 indirect effect & 0.125 & - & 0.360 \\
\hline & via CT1 indirect effect & 0.085 & - & 0.098 \\
\hline & via CP1 indirect effect & -0.043 & - & 0.012 \\
\hline & via $B C A$ indirect effect & 0.010 & - & 0.000 \\
\hline & Total & 0.613 & - & 0.653 \\
\hline \multirow{7}{*}{ CL2 } & CL2 direct effect & 0.699 & 0.981 & 0.098 \\
\hline & via CL1 indirect effect & 0.021 & -0.058 & 0.072 \\
\hline & via CL3 indirect effect & 0.160 & 0.132 & 0.463 \\
\hline & via CT1 indirect effect & 0.130 & -0.304 & 0.150 \\
\hline & via $\mathrm{CP} 1$ indirect effect & -0.071 & 0.165 & 0.020 \\
\hline & via $\mathrm{BCA}$ indirect effect & 0.021 & -0.018 & 0.000 \\
\hline & Total & 0.960 & 0.898 & 0.803 \\
\hline \multirow{7}{*}{ CL3 } & CL3 direct effect & 0.209 & 0.172 & 0.603 \\
\hline & via CL1 indirect effect & 0.022 & -0.061 & 0.076 \\
\hline & via CL2 indirect effect & 0.536 & 0.753 & 0.075 \\
\hline & via CT1 indirect effect & 0.148 & -0.347 & 0.171 \\
\hline & via CP1 indirect effect & -0.051 & 0.120 & 0.014 \\
\hline & via $\mathrm{BCA}$ indirect effect & 0.031 & -0.027 & 0.000 \\
\hline & Total & 0.894 & 0.611 & 0.939 \\
\hline \multirow{7}{*}{ CT1 } & CT1 direct effect & 0.174 & - & 0.201 \\
\hline & via CL1 indirect effect & 0.018 & - & 0.062 \\
\hline & via CL2 indirect effect & 0.522 & - & 0.073 \\
\hline & via CL3 indirect effect & 0.177 & - & 0.513 \\
\hline & via CP1 indirect effect & -0.056 & - & 0.016 \\
\hline & via $B C A$ indirect effect & 0.032 & - & 0.000 \\
\hline & Total & 0.867 & - & 0.864 \\
\hline \multirow{7}{*}{$\mathrm{CP} 1$} & CP1 direct effect & -0.080 & 0.186 & 0.022 \\
\hline & via CL1 indirect effect & 0.020 & -0.054 & 0.068 \\
\hline & via CL2 indirect effect & 0.621 & 0.871 & 0.087 \\
\hline & via CL3 indirect effect & 0.134 & 0.111 & 0.388 \\
\hline & via CT1 indirect effect & 0.122 & -0.285 & 0.141 \\
\hline & via $\mathrm{BCA}$ indirect effect & 0.020 & -0.017 & 0.000 \\
\hline & Total & 0.837 & 0.811 & 0.706 \\
\hline \multirow{7}{*}{$\mathrm{BCA}$} & BCA indirect effect & 0.044 & - & 0.001 \\
\hline & via CL1 indirect effect & 0.009 & - & 0.030 \\
\hline & via CL2 indirect effect & 0.327 & - & 0.046 \\
\hline & via CL3 indirect effect & 0.144 & - & 0.416 \\
\hline & via CT1 indirect effect & 0.126 & - & 0.145 \\
\hline & via $\mathrm{CP} 1$ indirect effect & -0.036 & - & 0.010 \\
\hline & Total & 0.613 & - & 0.647 \\
\hline \multicolumn{2}{|c|}{ Coefficient of determination } & 0.992 & 0.866 & 0.917 \\
\hline
\end{tabular}

Plant Group: PW - plant width, NC1 - first order cladode number, NC3 - third order cladode number; Cladode Group: CL1 - first order cladode length, CL2 - second order cladode length, CL3 - third order cladode length, CT1 - first order cladode thickness, CP1 - first order cladode perimeter, BCA - basal cladode area. "-“ indicates that the variable did not present any correlation of plant group variables.

Similar to IPA, in the MIU clone (Table 6) the characteristics of the $2^{\text {nd }}$ and $3^{\text {rd }}$ order cladodes were those that most explained the growth and structure of the plant. The perimeter and the thickness of the $3^{\text {rd }}$ order cladodes were those that most contributed to the highest PW and the highest number of cladodes of the $3^{\text {rd }}$ and $4^{\text {th }}$ orders, either directly or indirectly through other variables (BCT, CP2, CA4). Similarly, the greater the growth of the second-order cladodes (CP2), the greater the stimulus for the development of new first order cladodes ( $\mathrm{NC1}$ ). In addition, it was found that greater thicknesses of the $3^{\text {rd }}$ order cladodes provided a greater increase of the CAI. 
Table 6. Pearson's correlation coefficient unfolding on direct and indirect effects among the variables of the response group "Plant" (structural characteristics of the plants), with the variables of the "Cladode" explanatory group (structural characteristics of the cladodes), of the clone Miúda - MIU, under irrigated conditions, in a semi-arid environment.

\begin{tabular}{|c|c|c|c|c|c|c|}
\hline Variable & Effect & $\mathrm{PW}$ & $\mathrm{NC} 1$ & $\mathrm{NC} 3$ & $\mathrm{NC4}$ & CAI \\
\hline \multirow{6}{*}{ BCT } & BCT direct effect & - & - & 0.014 & 0.123 & 0.150 \\
\hline & via CT3 indirect effect & - & - & 0.430 & 0.605 & 0.313 \\
\hline & via $\mathrm{CP} 2$ indirect effect & - & - & -0.020 & -0.097 & 0.151 \\
\hline & via $\mathrm{CP} 3$ indirect effect & - & - & 0.470 & 0.270 & -0.040 \\
\hline & via CA4 indirect effect & - & - & -0.215 & -0.127 & 0.200 \\
\hline & Total & - & - & 0.679 & 0.775 & 0.774 \\
\hline \multirow{6}{*}{ CT3 } & CT3 direct effect & 1.242 & 0.142 & 0.554 & 0.779 & 0.403 \\
\hline & via $B C T$ indirect effect & -0.112 & 0.060 & 0.011 & 0.095 & 0.117 \\
\hline & via $\mathrm{CP} 2$ indirect effect & -0.056 & 0.739 & -0.038 & -0.186 & 0.292 \\
\hline & via $\mathrm{CP} 3$ indirect effect & -0.059 & 0.042 & 0.639 & 0.368 & -0.055 \\
\hline & via CA4 indirect effect & -0.249 & -0.417 & -0.224 & -0.132 & 0.208 \\
\hline & Total & 0.765 & 0.566 & 0.942 & 0.924 & 0.964 \\
\hline \multirow{6}{*}{$\mathrm{CP} 2$} & CP2 Direct effect & -0.072 & 0.961 & -0.050 & -0.242 & 0.380 \\
\hline & via $B C T$ indirect effect & -0.058 & 0.031 & 0.006 & 0.049 & 0.060 \\
\hline & via CT3 indirect effect & 0.955 & 0.109 & 0.426 & 0.599 & 0.310 \\
\hline & via $\mathrm{CP} 3$ indirect effect & -0.053 & 0.038 & 0.573 & 0.330 & -0.049 \\
\hline & via CA4 indirect effect & -0.155 & -0.260 & -0.139 & -0.082 & 0.129 \\
\hline & Total & 0.617 & 0.879 & 0.817 & 0.654 & 0.829 \\
\hline \multirow{6}{*}{$\mathrm{CP} 3$} & CP3 direct effect & -0.064 & 0.045 & 0.693 & 0.399 & -0.060 \\
\hline & via $B C T$ indirect effect & -0.098 & 0.053 & 0.010 & 0.083 & 0.102 \\
\hline & via CT3 indirect effect & 1.146 & 0.131 & 0.512 & 0.719 & 0.372 \\
\hline & via $\mathrm{CP} 2$ indirect effect & -0.060 & 0.796 & -0.041 & -0.201 & 0.314 \\
\hline & via CA4 indirect effect & -0.221 & -0.369 & -0.198 & -0.116 & 0.184 \\
\hline & Total & 0.703 & 0.656 & 0.975 & 0.884 & 0.913 \\
\hline \multirow{6}{*}{ CA4 } & CA4 Direct effect & -0.285 & - & -0.255 & -0.150 & 0.237 \\
\hline & via $B C T$ indirect effect & -0.122 & - & 0.012 & 0.104 & 0.127 \\
\hline & via CT3 indirect effect & 1.088 & - & 0.486 & 0.683 & 0.353 \\
\hline & via $\mathrm{CP} 2$ indirect effect & -0.039 & - & -0.027 & -0.132 & 0.207 \\
\hline & via $\mathrm{CP} 3$ indirect effect & -0.049 & - & 0.537 & 0.309 & -0.046 \\
\hline & Total & 0.592 & - & 0.752 & 0.813 & 0.878 \\
\hline \multicolumn{2}{|c|}{ Coefficient of determination } & 0.619 & 0.841 & 0.974 & 0.887 & 0.974 \\
\hline
\end{tabular}

Where: Plant group: PH - plant height, PT - plant thickness, NC1 - first order cladode number, NC3 - third order cladode number, NC4 - fourth order cladode number, CAI - cladode area index; Cladode group: BCT - basal cladode thickness, CT3 - third order cladode thickness, CP2 - second order cladode perimeter, CP3 - third order cladode perimeter, CA4 - fourth order cladode area "-“" indicates that the variable did not present any correlation with one of the variables of the plant group.

The morphogenesis of the cladodes affected canopy formation of the plants, and for the MIU and IPA clones of Nopalea genus, the growth of the $2^{\text {nd }}$ and $3^{\text {rd }}$ order cladodes subsidized plant growth (canopy width, increase of CAI and appearance of new cladodes of lower or higher orders). This finding can be explained by the location of these cladodes $\left(2^{\text {nd }}\right.$ and $3^{\text {rd }}$ orders) in the upper part of the plant. Thus, incident solar radiation on them is higher than the incident on lower order cladodes, which are 
partially or completely shaded.

According to Nobel (2001), young cladodes display greater stimulus for photosynthesis than those of lower orders, contributing more to plant growth, as well as to the appearance of new cladodes. Acevedo, Badilla, and Nobel (1983) reported that this occurs because there are differences in the pattern of solar radiation interception by the distinct cladodes over the day, as well as by their side of exposure in relation to the apparent movement of the sun.

Table 7. Pearson's correlation coefficient unfolding of direct and indirect effects among the variables of the response group "Plant" (structural characteristics of plants), with the variables of the explanatory group "Cladode" (structural characteristics of cladodes), clone Orelha de Elefante Mexicana - OEM under irrigated conditions, in a semi-arid environment.

\begin{tabular}{|c|c|c|c|c|c|}
\hline Variable & Effect & $\mathrm{PH}$ & $\mathrm{NC1}$ & $\mathrm{NC3}$ & CAI \\
\hline \multirow{7}{*}{ CL1 } & CL1direct effect & 1.462 & - & 0.441 & 0.871 \\
\hline & via ECB & -0.390 & - & -0.088 & -0.054 \\
\hline & via $\mathrm{EC} 1$ indirect effect & -0.113 & - & 0.899 & 0.243 \\
\hline & via EC3 indirect effect & -0.012 & - & -0.355 & -0.127 \\
\hline & via PC1 indirect effect & -0.155 & - & -0.169 & -0.045 \\
\hline & via $\mathrm{BCA}$ indirect effect & 0.098 & - & -0.093 & 0.066 \\
\hline & Total & 0.889 & - & 0.635 & 0.953 \\
\hline \multirow{7}{*}{ BCT } & BCT direct effect & -0.456 & - & -0.103 & -0.064 \\
\hline & via CL1 indirect effect & 1.252 & - & 0.378 & 0.745 \\
\hline & via CT1 indirect effect & -0.102 & - & 0.815 & 0.220 \\
\hline & via CT3 indirect effect & -0.008 & - & -0.228 & -0.081 \\
\hline & via CP1 indirect effect & -0.142 & - & -0.154 & -0.041 \\
\hline & via $\mathrm{BCA}$ indirect effect & 0.095 & - & -0.090 & 0.064 \\
\hline & Total & 0.639 & - & 0.617 & 0.844 \\
\hline \multirow{7}{*}{$\mathrm{EC} 1$} & CT1 direct effect & -0.126 & - & 1.006 & 0.272 \\
\hline & via CL1 indirect effect & 1.306 & - & 0.394 & 0.778 \\
\hline & via $\mathrm{BCT}$ indirect effect & -0.369 & - & -0.083 & -0.051 \\
\hline & via CT3 indirect effect & -0.010 & - & -0.292 & -0.104 \\
\hline & via CP1 indirect effect & -0.149 & - & -0.162 & -0.043 \\
\hline & via $\mathrm{BCA}$ indirect effect & 0.092 & - & -0.088 & 0.062 \\
\hline & Total & 0.744 & - & 0.775 & 0.913 \\
\hline \multirow{7}{*}{$\mathrm{EC} 3$} & CT3 direct effect & -0.016 & -0.987 & - & -0.169 \\
\hline & via CL1 indirect effect & 1.098 & -0.225 & - & 0.654 \\
\hline & via $B C T$ indirect effect & -0.220 & 0.057 & - & -0.031 \\
\hline & via CT1 indirect effect & -0.078 & 0.443 & - & 0.168 \\
\hline & via CP1 indirect effect & -0.109 & -0.153 & - & -0.031 \\
\hline & via $\mathrm{BCA}$ indirect effect & 0.025 & -0.002 & - & 0.017 \\
\hline & Total & 0.700 & -0.868 & - & 0.608 \\
\hline \multirow{7}{*}{$\mathrm{PC} 1$} & CP1 direct effect PC1 & -0.183 & - & - & -0.053 \\
\hline & via CL1 indirect effect & 1.245 & - & - & 0.741 \\
\hline & via $\mathrm{BCT}$ indirect effect & -0.354 & - & - & -0.049 \\
\hline & via CT1 indirect effect & -0.103 & - & - & 0.221 \\
\hline & via CT3 indirect effect & -0.010 & - & - & -0.100 \\
\hline & via $\mathrm{BCA}$ indirect effect & 0.128 & - & - & 0.086 \\
\hline & Total & 0.724 & - & - & 0.847 \\
\hline \multirow{8}{*}{$\mathrm{BCA}$} & BCA direct effect ACB & - & - & - & 0.137 \\
\hline & via $\mathrm{CC} 1$ indirect effect & - & - & - & 0.417 \\
\hline & via ECB indirect effect & - & - & - & -0.030 \\
\hline & via EC1 indirect effect & - & - & - & 0.123 \\
\hline & via EC3 indirect effect & - & - & - & -0.021 \\
\hline & via $\mathrm{PC} 1$ indirect effect & - & - & - & -0.033 \\
\hline & Total & - & - & - & 0.595 \\
\hline & f determination & 0.877 & 0.897 & 0.711 & 0.959 \\
\hline
\end{tabular}

Where: Plant Group: PH - plant height, NC1 - first order cladode number, NC3 - third order cladode number, IAC - cladode area index; Cladode group: CC1 - first order cladode number, ECB - basal cladode thickness, EC1 - first order cladode thickness, EC3 - third order cladode thickness, PC1 - first order cladode perimeter, ACB - basal area cladode. ". "indicates that the variable did not present any correlation with one of the variables of the plant group. 
Silva et al. (2015), in a study with clones IPA and Miúda, with data obtained at 754 days after cut, showed that $2^{\text {nd }}$ and $3^{\text {rd }}$ order cladodes were the largest for these clones. Cunha et al. (2012) reported that there is a correlation between the rate of appearance of new cladodes and the number of cladodes present in the plant because each unit that emerges represents an additional potential for the appearance of new cladodes. These new structural units will perform more photosynthesis and will produce more photoassimilates, which will stimulate plant growth.

Using four years and eight months old MIU clones, Pinheiro et al. (2014) studied the contribution of the growth characteristics of cladodes and plants to the cladode area index, observing the existence of a significant correlation with the height $\times$ width product and the characteristics of $1^{\text {st }}, 2^{\text {nd }}, 3^{\text {rd }}$ and $4^{\text {th }}$ order cladodes. However, the authors pointed out that the characteristics of the fourth-order cladodes were the ones that contributed the most to the IAC clone. The other correlations were of low magnitude.

For the OEM clone (Table 7), higher lengths and thicknesses of the $1^{\text {st }}$ order cladodes (CL1 and CT1) contributed to the occurrence of larger plants, with a higher number of $3^{\text {rd }}$ order cladodes and higher CAI values, which were verified by means of direct or indirect effects (via BCT, CT3, CP1, BCA). In turn, the lower growth of the $3^{\text {rd }}$ order cladodes (CT3) stimulated the development of new $1^{\text {st }}$ order cladodes.

The major contribution of the first order cladodes to the OEM clone is because these are more numerous than those of the other orders. Clones of the genus Opuntia exhibit fewer cladodes when compared to clones of the genus Nopalea, but their cladodes are larger (CAVALCANTE et al., 2014) and play an important role in the growth and storage of water and plant mass.

Silva et al. (2015) report that first order cladodes are the largest in the OEM clone, as the second-order cladodes. The authors highlight that, similarly to the IPA clone; the OEM clone has larger perimeters of basal and first order cladodes when compared to the Miúda clone.

When evaluating the contribution of the morphological characteristics of plants and cladodes to the increase of the cladode area index of the Orelha de Elefante Mexicana clone, Pinheiro et al. (2014) found that the morphological characteristics explained $63.69 \%$ of the variation of the cladode area index. The variable that had the greatest weight in this percentage was the total number of cladodes of the plants.

Silva et al. (2010) emphasize that the study of morphological characteristics of clones is important since they will determine the growth habit of the latter, which can be erect or half-open. This habit is directly related to the interception of solar radiation by plants, determined by the architecture of its canopy.

\section{CONCLUSIONS}

The relationships between the characteristics of the cladodes and the forage cactus plant were more associated with genus peculiarities than with the different clones.

The growth of the $2^{\text {nd }}$ and $3^{\text {rd }}$ order cladodes was the characteristic that most contributed to the canopy formation of clones of plants of the genus Nopalea (IPA and Miúda), whereas for Orelha de Elefante Mexicana of the genus Opuntia, it was the first and third order cladodes that most contributed.

\section{ACKNOWLEDGEMENTS}

To FACEPE for the financial support (APQ0215-5.01/10) and to CAPES for scholarship granting.

\section{REFERENCES}

ACEVEDO, E.; BADILLA, I.; NOBEL, P. S. Water relations, diurnal acidity changes, and productivity of a cultivated cactus, Opuntia ficus-indica. Plant Physiology, Amsterdam, v. 72, n. 3, p. 775-780, 1983.

BRUM, B. et al. Correlações canônicas entre variáveis de semente, plântula, planta e produção de grãos em mamoneira. Ciência Rural, Santa Maria, v. 41, n. 3 , p. 404-411, 2011

CAVALCANTE, L. A. D. et al. Respostas de genótipos de palma forrageira a diferentes densidades de cultivo. Pesquisa Agropecuária Tropical, Goiânia, v. 44, n. 4, p. 424-433, 2014.

CRUZ, C. D. Programa Genes: biometria. 1. ed. Viçosa, MG: Editora UFV, 2006. 382 p.

CUNHA, D. N. F. V. et al. Morfometria e acúmulo de biomassa em palma forrageira sob doses de nitrogênio. Revista Brasileira de Saúde e Produção Animal, Salvador, v. 13, n. 4, p. 11561165, 2012.

FERREIRA, D. F. Estatística Multivariada. 2. ed. Lavras, MG: Editora UFLA, 2011. 675 p.

FLORES-HERNÁNDEZ, A. et al. Yield and physiological traits of prickly pear cactus 'nopal' (Opuntia spp.) cultivars under drip irrigation. Agricultural Water Management, Amsterdam, v. 70, n. 1, p. 97-107, 2004. 
GIBSON, et al. Exploiting leaf starch synthesis as a transient sink to elevate photosynthesis, plant productivity and yields. Plant science, Amsterdam, v. 181, n. 3, p. 275-281, 2011.

NEDER, D. G. et al. Correlations and path analysis of morphological and yield traits of cactus pear accessions. Crop Breeding and Applied Biotechnology, Amsterdam, v. 13, n. 3, p. 203-207, 2013.

NOBEL, P. S. Ecophysiology of Opuntia ficusindica. In: MONDRAGÓN-JACOBO, C.; PÉREZGONZÁlEZ, S. (Eds.). Cactus (Opuntia spp.) as forage. Rome: Food and Agriculture Organization of the United Nations, 2001. p. 13-20. (FAO Plant production and protection paper, 169).

PEÑA-VALDIVIA, C. B. et al. Morphological characterization of Opuntia spp.: a multivariate analysis. Journal of the Professional Association for Cactus Development, Chapingo, v. 10, n. 1, p. 1 $-21,2008$.

PINHEIRO, K. M. et al. Correlações do índice de área do cladódio com características morfogênicas e produtivas da palma forrageira. Pesquisa Agropecuária Brasileira, Brasília, v. 49, n. 12, p. 939-947, 2014.

QUEIROZ, M. G. et al. Características morfofisiológicas e produtividade da palma forrageira sob diferentes lâminas de irrigação. Revista Brasileira de Engenharia Agrícola e Ambiental, Campina Grande, v. 19, n. 10, p. 931938, 2015.

SILVA, C. C. F.; SANTOS, L. C. Palma Forrageira (Opuntia ficus-indica Mill) como alternativa na alimentação de ruminantes. Revista Electrónica de Veterinária, Málaga, v. 7, n. 10, p. 1-13, 2006.

SILVA, N. G. M. et al. Relação entre características morfológicas e produtivas de clones de palmaforrageira. Revista Brasileira de Zootecnia, Viçosa, v. 39, n. 11 , p. $2389-2397,2010$

SILVA, T. G. F. et al. Indicadores de eficiência do uso da água e de nutrientes de clones de palma forrageira em condições de sequeiro no Semiárido brasileiro. Bragantia, Campinas, v. 73, n. 2, p. 184191, 2014a.

SILVA, T. G. F. et al. Área do cladódio de clones de palma forrageira: modelagem, análise e aplicabilidade. Revista Brasileira de Ciências Agrárias, Recife, v. 9, n. 4, p. 633-641, 2014b. de clones de palma forrageira no semiárido e relações com variáveis meteorológicas. Revista Caatinga, Mossoró, v. 28, n. 2, p. 10-18, 2015.

THOMAZ, G. L. et al. Produção do girassol e teor de óleo nos aquênios em função da temperatura do ar, precipitação pluvial e radiação solar. Ciência Rural, Santa Maria, v. 42, n. 8, p. 1380-1385, 2012.

TOEBE, M.; CARGNELUTTI FILHO, A. Não normalidade multivariada e multicolinearidade na análise de trilha em milho. Pesquisa Agropecuária Brasileira, Brasília, v. 48, n. 5, p. 466-477, 2013.

WEERAKKODY, W. A. P.; SURIYAGODA, L. D. B. Estimation of leaf and canopy photosynthesis of pot chrysanthemum and its implication on intensive canopy management. Scientia Horticulturae, Amsterdam, v. 192, n. 1, p. 237-243, 2015.

SILVA, T. G. F. et al. Crescimento e produtividade 